\title{
THE RELEVANT CHALLENGES FOR HUMAN RESOURCES MANAGEMENT IN PRESENT- DAYS ORGANIZATIONS IN THE EUROPEAN UNION
}

\author{
Liudmila Lobanova \\ Vilnius Gediminas Technical University, Saulettekio al. 11, LT-10223 Vilnius, Lithuania \\ E-mail: liudmila.lobanova@vgtu.lt
}

\begin{abstract}
Human resources management systems in different organisations must be adequate to the needs to adapt themselves to the cohesion challenges in the European Union. The main objective of the following paper is to assess which circumstances of cohesion processes are perceived as relevant challenges for activities of organizations and for human resources management in present-day organisations. The research results can be used in practice of the organisations of a different profile when improving human resources management and responding to the cohesion challenges and needs by means of human resources management instruments.
\end{abstract}

Keywords: European integration, European Union, Human Resources Management, cohesion processes, social cohesion, challenges for organizations.

JEL Classification: D03; M1; M5; M14; O15.

\section{Introduction}

It is vitally important for the EU society to create such forms of economic, social and territorial cohesion, which would realistically help put into practice the EU sustainable development ideas laid down in the strategies Europe 2020 and Europe 2030. At the current stage of European integration, in fulfilling the cohesion policy aims for 20142020 period, cohesion is the number one priority within the context of the sustainable development principles, all the more so, that merely setting the aims and challenges to intensify the sustainable development processes and consolidation of finances are insufficient. Taking into consideration the fact that the sustainable development and cohesion ideas are considered to be an inseparable part of the European Union politics (Cini, Borragan 2013), it is noticed that there is not only a lack of more detailed investigations (devoted to the problems of cohesion in particular) but also the dissemination of the ideas of the cohesion policy understandable to society is inadequate.

Though cohesion is one of the most important values of the European Union, the meaning of the concept of cohesion itself has not been characterised sufficiently reasonably taking into consideration the context of EU integration, development and expansion. It should be underlined that the concept of cohesion was introduced into the EU political documents "without an exact definition" (Begg 2010; Molle 2007).
Despite the variety of viewpoints, in the most general case the concept of cohesion is usually treated as a rapprochement expressing the striving to reduce differences typical of a certain sphere of public life or activity. Social coherence is, first of all, a qualitative category, which reflects consistency of social and institutional relations, which are necessary to ensure people's common welfare (Council of Europe 2005).

The object of this article is circumstances of cohesion processes in European Union and its challenges for human resources management.

The main objective is to assess which circumstances of cohesion processes are perceived as relevant challenges for activities of organizations and for human resources management in present-day organisations.

\section{Circumstances of cohesion processes}

Under current conditions of European integration, the circumstances reflecting cohesion between different cultures, mentalities, as well as between different lifestyles and even between different ideologies and the systems of values are singled out as exceptionally important. It is obvious that the necessity to respond to different cohesions and the circumstances of the need for it determine the inevitability of respective actions and changes in different spheres of management and managerial activities. 
At the present stage of the EU development and expansion the solutions, which would create the possibility not only to react to the challenges posed by the cohesion processes but also to meet common European standards, ethnic and other standards attributable to the improvement of the internal environment of the organisations, are necessary. Such solutions can be created by integrating the conceptions of human resources management and human resources management improvement into the cohesion policy.

Cohesion processes manifesting themselves in the conditions of European integration and the EU development and expansion are not noted only for great complexity and variety but they also require an adequate reaction to specific cohesion circumstances characteristic of the European and EU space. The priority role within this context is played by the circumstances characterising human resources management because it is these circumstances that are related in one way or another to all the circumstances of the expression of cohesion processes, cohesion between different organisations and different subjects of various activity on the local scale, in particular.

Having made the analysis of the problems of scientific research devoted to the contemporary concept of cohesion and the cohesion processes, it has been established that scientific discussions were sooner focused on the aspects of microeconomic and political cohesion processes. Too little attention was paid to the investigation of the cohesion processes at the meso and micro levels the territory of whose manifestation is the organisation and interaction between the people working in it.

The problems of the research devoted to improving management of the organisations is only partly related to the topical issues of the cohesion processes - the research does not specify the impact of the cohesion processes on the cohesion problems that occur in the organisations and are to be solved by managerial instruments.

Modern complexity cohesion processes, their circumstances and characteristics were analyzed by various scientists (Dimeglio et al. 2013; Brady 2010; Crane, Matten 2010; Harrison 2010; Brookes, Grint 2010; Ambros, Schlegelmilch 2009; Wiener, Diez 2009; Button 2008; Bachtler, Gorzelak 2009; Rakauskiene, Ivashinenko 2011; Ginevičius 2009; Ginevičius et al. 2014; Chan et al. 2006; Chang et al. 2013; Norton, De Haan 2013; Brakman et al. 2006; Melnikas 2012; Lobanova, Melnikas 2012; Lobanova 2015; Misiūnas, Balsyte 2009; Hix 2007; Forrest, Kearns 2001; Berger-Schmitt 2000; Bernard 1999; McCracken
2003; Oxoby 2009; Boucher, Samad 2013; Heidenreich et al. 2014).

The main tipes of cohesion and cirtumstances of cohesion processes have been revealed in Table 1 .

Table 1. The main types of cohesion (Source: Lobanova 2015; Melnikas 2012; Lobanova, Melnikas 2012)

\begin{tabular}{l|l}
\hline Types of cohesion & $\begin{array}{l}\text { Circumstances of cohesion } \\
\text { processes }\end{array}$ \\
\hline $\begin{array}{l}\text { The cohesion between } \\
\text { various processes }\end{array}$ & $\begin{array}{l}\text { The cohesion between econom- } \\
\text { ic, social, political, technologi- } \\
\text { cal development or other pro- } \\
\text { cesses }\end{array}$ \\
\hline $\begin{array}{l}\text { The cohesion between } \\
\text { various regions or } \\
\text { other geographically } \\
\text { identified spaces }\end{array}$ & $\begin{array}{l}\text { The cohesion between globally, } \\
\text { internationally, nationally or } \\
\text { even locally described regions }\end{array}$ \\
\hline $\begin{array}{l}\text { The cohesion between } \\
\text { various social groups } \\
\text { or social layers }\end{array}$ & $\begin{array}{l}\text { Social groups or social layers } \\
\text { may be considered and as- } \\
\text { sessed globally, internationally, } \\
\text { nationally or even locally }\end{array}$ \\
\hline $\begin{array}{l}\text { The cohesion between } \\
\text { various activities }\end{array}$ & $\begin{array}{l}\text { The cohesion between the sec- } \\
\text { tors of social, economic, politi- } \\
\text { cal, cultural, scientific and } \\
\text { technological development, as } \\
\text { well as various spheres of so- } \\
\text { cial activities or business }\end{array}$ \\
\hline $\begin{array}{l}\text { The cohesion between } \\
\text { various organizations } \\
\text { or subjects }\end{array}$ & $\begin{array}{l}\text { Various organizations or sub- } \\
\text { jects are engaged in various } \\
\text { activities }\end{array}$ \\
\hline gies
\end{tabular}

General principles of cohesion, which can help establish certain guidelines for selecting managerial impact measures are discussed in this paper. The main types of cohesion are following (Melnikas 2012; Lobanova, Melnikas 2012; Lobanova 2015):

- the cohesion between various processes: between economic, social, political, technological development or other processes, as well as between social and economic processes, between technological development and environmental protection or between other combinations of processes;

- the cohesion between various regions or other geographically identified spaces: in this case, the cohesion between globally, internationally, nationally or even locally described regions, may be mentioned;

- the cohesion between various social groups or social layers, which may be 
considered and assessed globally, internationally, nationally or even locally;

- the cohesion between various activities, between the sectors of social, economic, political, cultural, scientific and technological development, as well as various spheres of social activities or business;

- the cohesion between various organizations or subjects engaged in various activities;

- the cohesion between cultures and ideologies: between cultures, mentalities, lifestyles and value systems, as well as requiring harmonization between ideologies, which are scattered or propagating in the European Union area and all kinds of cohesion among individuals, especially interacting modern networking tools for use conditions.

The circumstances formed in the conditions of the cohesion processes in the European Union, which are of significance to human resources management improvement in business and public sector organisations, have been identified devoting main attention to work force flows intensifying under conditions of free movement of work force and free movement of natural persons, to intellectual and cultural exchange, new manifestations of cultures and mentalities, organisation of work and the variety of economic promotion systems, a rapid technological progress and new forms of competing and competition, especially with the intensification of processes of creating common labour markets.

In generalising the problems of scientific research devoted to the cohesion processes the conclusion can be drawn that not only new theoretical and empirical investigations are necessary to be carried out but also it is necessary to improve scientific research methods devoted to the investigation of the cohesion processes. The methodological breakthrough would help form a new way of thinking necessary to improve the cohesion policy and adopt, as well as implement, managerial solutions, which are adequate to the new possible cohesion challenges arising in the contradictory conditions of European integration and the EU development and expansion.

\section{Whose interests should human resources management be improved}

In discovering many different theories, concepts and viewpoints in modern management science devoted to the investigation and solution of human resources management problems, the conclusion is to be drawn that human resources management, which emerged as a result of challenges posed by certain historical circumstances, can and must be further improved in response to the new challenges and needs of the social and economic development that were historically formed. The discussions about the perspectives of improving human resources management models in Europe raise the question that is especially important under conditions of European integration: following whose interests should human resources management be investigated and improved?

In identifying the regularities in the change in human resources management paradigms, attention should be paid to the links between the causes of their interface with the essential changes taking place in society, economics and science, which were determined by the global transformation processes, and of late, especially in the European Union, by integration and the cohesion processes.

Two main stages can be distinguished in the evolution and improvement process of the human resources management paradigm (Lobanova 2015):

- During the first stage, in response to the challenges posed by a globally increasing competition, methods of quantitative formalisation of human resources management aims and functions formed for the substantiation of which such circumstances as integration of universal quantity management systems into management of organisations, the development of the solution adoption theories, commercialisation of the staff selection and assessment methods, strengthening of the roles of linear managers when planning and managing human resources and managing human resources, as well as creating the human resources policy were favourable;

- During the second stage the development of strategic management methods under conditions of the creation of international markets when not only theories of strategic management and international marketing but also theories of human capital and talent management formed, had a great impact on the human resources management improvement, which required the substantiation of the new criteria for measuring the value of human resources combining methods of quantitative formalisation and qualitative assessment preserving an increase in competitive edge as the major goal of human resources management improvement. 
The recent decade has distinguished itself for the fact that socially oriented approaches to the social, economic and human development are ever more intensely integrated (or rhetorically declared) in management practice. However, lessons of history of discrepancy between rhetoric and reality should be a serious warning of the fact that "politically engaged" ideas of human management and social welfare are corrected taking into consideration the positions of all interested countries.

The contemporary human resources management theory tries to reconcile different paradigms the present, already formed paradigm that is oriented towards a rational approach to the human resources development following the principles of cost effectiveness and basing oneself in essence on the quantitative formalisation methods, as well as a new socially-oriented paradigm being formed, which provides for integration of cohesion and sustainability principles into human resources management practice.

Major objectives of improving human resources and their management, measures of realising these objectives and ways of formalising the results determine difference between these paradigms. The "European" contextual human resources management model proposed almost three decades ago was not sufficiently concretely discussed by the scientists though the main insights into its benefit were presented and some achievements were mentioned.

Responding to the cohesion needs in the conditions of the intensifying coherence processes, the improvement of the "European" human resources management model must be assessed not only as a challenge but also as a possibility, making use of the historical situation, to implement the sociallyoriented human resources management model in Europe under conditions of creating social market economy. In assessing purposeful cohesion as a major precondition and a programme measure to achieve that processes of European integration and the EU development and expansion should be realistically oriented towards the principles of humanism, democracy, ecology, morality and social responsibility, a conceptual theoretical model devoted to human resources management in the conditions of the cohesion processes in the European Union is proposed by author (Lobanova 2015).

In summing up the results of the analysis of the cohesion processes and their circumstances, and taking into consideration the established regularities of the change in the human resources management paradigm, the conclusion can be drawn that in the conditions of the cohesion processes in the European Union challenges of two types posed to the human resources management improvement reveal themselves:

- challenges arising from the EU development priorities formulated in the political directives and strategic and programme documents;

- challenges arising from insufficient scientific knowledge of human resources management under conditions of European integration.

In both cases the needs to purposefully improve human resources management are determined by the new circumstances of the cohesion processes that constantly reveal themselves. It can be stated that cohesion can be understood as a constantly operating human resources management improvement factor and it is necessary to respond to it uninterruptedly by human resources management improvement instruments being actualised.

\section{Relevant challenges of the circumstances of cohesion processes and its impact on human resources management}

The objective of research is to assess which circumstances of cohesion processes are perceived as relevant challenges for activities of organizations and human resources management in present-day organisations.

The research methods: by means of the case analysis method in the chosen Lithuanian and Latvian organisations, circumstances of cohesion processes and practice of applying different management standards, methods and systems (social, responsibility, social accountability, quality management, etc.) were evaluated establishing which standards, methods or systems are or can be related to the regulation of labour relations and other human resources management processes. In applying the case analysis method 16 organisations in Lithuania and 12 organisations in Latvia have been studied (both business and public sector organisations).

Findings of research. Circumstances of cohesion processes are perceived as relevant challenges for activities of organizations and its human resources management. Several cohesion circumstances recognized as posing challenges for activities of organizations and human resources management.

The challenges posed by the cohesion between various processes (between economic, social, political, technological development or other 
processes) noted 62.5 percent organizations in Lithuania and 50.0 percent organisations in Latvia.

The challenges posed by the cohesion between various regions or other geographically identified spaces (between globally, internationally, nationally or even locally described regions) has recognized like relevance 43.75 percent organizations in Lithuania and 41.6 percent organisations in Latvia.

The challenges posed by the cohesion between various social groups or social layers are actual for 62.5 percent Lithuanian and 66.6 per cent Latvian organizations. Social groups or social layers may be considered and assessed globally, internationally, nationally or even locally.

The cohesion between various activities (between the sectors of social, economic, political, cultural, scientific and technological development, as well as various spheres of social activities or business) takes care of 75.0 percent Lithuanian and 66.6 percent Latvian organizations.

The cohesion between organizational and operational subjects (various organizations or subjects are engaged in various activities) is relevant for 56.25 percent Lithuanian and 91.6 percent Latvian organizations. 2014 investigation has shown, that the cohesion between cultures and ideologies (between cultures, mentalities, lifestyles, value systems and ideologies) was less concern for organisations (these circumstances recognized the challenges for 31.25 percent of Lithuanian and for 41.6 percent of Latvian organizations).

Global and international cohesion processes circumstances were marked as less relevant than national and local scale processes of cohesion for Lithuanian and Latvian organizations and its human resource management in the 2014 study. The global cohesion circumstances recognized as challenges 25 percent Lithuanian and 33.3 percent Latvian organizations. The international cohesion processes raises concerns about 56.25 percent Lithuanian and 58.3 percent Latvian organizations.

Since 2015 in Europe are intensifying migration processes and problems of refugees allocation. Therefore, global and international cohesion processes are becoming extremely serious challenge for organisations. Systemic solutions of different levels, oriented to the global, international, national and local, i.e. the level of organization, overcoming challenges required in present time.

The practice of applying different management standards, methods and systems were evaluated in Lithuanian and Latvian organizations establishing which standards, methods or systems are or can be related to to respond to the cohesion chal- lenges. It was found that social responsibility guidance standard (ISO 26000) is guided by 18.75 percent of the analyzed organizations in Lithuania and 25 percent of the analyzed organizations in Latvia.

Quality Management System (International standart ISO 9001) are installed on 43.75 percent of the analyzed organizations in Lithuania and 41.66 percent of the analyzed organizations in Latvia.

Social Accountability standard (SA8000) is integrated into the management processes of 25.0 percent of Lithuanian and 33.3 percent of organizations.

Environmental Management Systems Standard (ISO 14001) is guided in 50 percent organizations in Lithuania and Latvia (almost all of them are production companies).

Environmental Management and Audit Scheme EMAS is applied in 18.75 percent of organizations in Lithuania and in 25 percent of Latvian organizations.

AA1000 series accountability standards included in the 12.5 percent of Lithuanian organizations and 16.6 percent of Latvian organizations. In comparison number of surveyed organizations are socially responsible. This can be explained by the fact that the invitation to participate in a case study responded transparency distinguished organizations. However, the Occupational Safety and Health Management System Requirements (BS OHSAS 18001: 2007) is applied to only 31.25 percent of organizations in Lithuania and 25 percent in Latvia examined organizations.

Based on the trends that have been identified, it can be assumed that the responsible human resource management related advanced management methods, standards and regulations are not yet sufficiently understood as being likely to be useful in responding to the intensifying processes of cohesion challenges.

It was found that both in Lithuanian and Latvian organizations management practices are applied a variety of other methods: a standardized system of working LEAN, Seven Sigma (7S) model, balanced scorecard system (BSS), the Management by Objectives method (MBO), employee assessment system and competence development and evaluation models and others.

A variety of management methods and standarts (Table 2) are recognized as useful and effective not only in terms of their direct purpose, but also in response to the challenges of cohesion and harmonizing human resources management processes. 
Table 2. The utility of management methods and standarts, percent (the case of Lithuanian organizations) (Source: Lobanova 2015)

\begin{tabular}{l|c}
\hline Management methods and standards & $\begin{array}{l}\text { Benefiting } \\
\text { (percent) }\end{array}$ \\
\hline $\begin{array}{l}\text { ISO 9000 series standards (quality } \\
\text { management principles) }\end{array}$ & 81.8 \\
\hline $\begin{array}{l}\text { Quality Management System (ISO 9001 } \\
\text { series standards) }\end{array}$ & 75.0 \\
\hline Social Accountability standard (SA8000) & 85.7 \\
\hline $\begin{array}{l}\text { Social responsibility guidance standard } \\
\text { (ISO 26000) }\end{array}$ & 50.0 \\
\hline $\begin{array}{l}\text { Environmental Management Standard } \\
\text { (ISO 14001) }\end{array}$ & 50.0 \\
\hline $\begin{array}{l}\text { Occupational Safety and Health } \\
\text { Management System Requirements (BS }\end{array}$ & 87.5 \\
$\begin{array}{l}\text { OHSAS 18001: 2007) } \\
\text { Environmental Management and Audit } \\
\text { Scheme EMAS }\end{array}$ & 16.7 \\
\hline AA1000 series accountability standards & 20.0 \\
\hline Standardized system of working LEAN & 66,7 \\
\hline $360^{\circ}$ feedback method & 91.7 \\
\hline Another standards, systems or methods & 71.4 \\
\hline
\end{tabular}

The benefits of advanced management methods and standards for improvement of human resource management systems in organizations was carried out by questioning personnel managers and specialists that are members of Personell Management Professionals Association (PVPA) in Lithuania.

This survey revealed a clear trend that most valued methods and standards were considered useful to harmonize not only the human resources management processes, but also the entire organization's management system.

81.8 percent of personnel managers and specialists, who are members of Human Resources Management Professionals Association, indicated that more benefiting for organizations are ISO 9000 series standarts apply to implement quality managent principles (Hoyle 2001).

Occupational Safety and Health Management System Requirements (BS OHSAS 18001: 2007) has been marked as benefiting by 87.5 percent of respondents.

Especially important and useful recognized methods, which increases the responsibility and awareness of information security. ISO 27001 standard promotes the development of a process approach to the organization's information security management system design, installation, implementation, monitoring, reviewing, maintaining and improving (Informations security and ISO 27001 2013). This method is recognized as contributing to the human resource management system sustainability.
Social responsibility guidance standard (ISO 26000) has been marked as benefiting only by 50 percent of personell managers and specialists.

The annual employee performance evaluation with $360^{\circ}$ feedback method has been marked as useful in an anonymous employee survey tool, which includes questions about leadership, quality, online manual, labor climate and so on. $360^{\circ}$ feedback method has been marked as useful by 91.7 percent of respondents.

Another standards, systems or methods (such as standardized system of working LEAN, Seven Sigma model, balanced scorecard system, the Management by Objectives method, employee assessment system and competence development and evaluation models and others) has been marked as useful by 71.4 percent of respondents.

Summing up the results it is worth noting that many of the management practices and standards that apply to organizations may be an appropriate response to the challenges of cohesion.

\section{Conclusions}

At the present stage of European integration and the development and expansion of the European Union the problem whose essence has been determined by the fact that a response given to the new challenges and needs arising under conditions of cohesion processes in practice of many organisations by means of human resources management instruments is inappropriate.

The main tipes of cohesion and cirtumstances of cohesion processes have been revealed: the cohesion between various processes, the cohesion between various regions or other geographically identified spaces, the cohesion between various social groups or social layers, the cohesion between various activities, between the sectors of social, economic, political, cultural, scientific and technological development, as well as various spheres of social activities or business, the cohesion between various organizations or subjects engaged in various activities, the cohesion between cultures and ideologies.

In identifying the regularities in the change in human resources management paradigms, attention should be paid to the links between the causes of their interface with the essential changes taking place in society, economics and science, which were determined by the global transformation processes, and of late, especially in the European Union, by integration and the cohesion processes.

The contemporary human resources management theory tries to reconcile different para- 
digms - the present, already formed paradigm that is oriented towards a rational approach to the human resources development following the principles of cost effectiveness and basing oneself in essence on the quantitative formalisation methods, as well as a new socially-oriented paradigm being formed, which provides for integration of cohesion and sustainability principles into human resources management practice.

Having carried out the investigations the most important human resources management and other management methods applied in modern managerial practice of the organisations were considered and assessed devoting main attention to their adequacy to the needs determined by cohesion in the European Union, as well as to the identification and justification of the criteria for evaluating the cohesion problems and circumstances.

The challenges posed by the cohesion processes in the present-day conditions of European integration and the EU development and expansion determine the dilemma of a complicated choice of each organisation in assessing the priorities of cost effectiveness and social justice.

Complex empirical investigations aimed at assessing adequacy and adaptability of human resources management methods and models in the conditions of the cohesion processes in the EU enable several important trends to be highlighted, which will help not only to assess the cohesion challenges occurring at the present stage but also to forecast what new cohesion challenges the organisations must be ready to respond to in the future by means of human resources management instruments themselves.

On the basis of the challenges posed to human resources management by the cohesion processes established in this article, it is proposed to relate cohesion-oriented human resources management practices to the implementation of the general cohesion principles in the organisations.

\section{Contribution}

Author is welcome to declare any involvement in writing a manuscript (e.g. conception and design of the work, acquisition of data, or analysis and interpretation of data, drafting the article or revising it critically for important intellectual content, etc.).

\section{Disclosure statement}

Author is required to include a statement at the end of their article to declare whether or not they have any competing financial, professional, or personal interests from other parties.

\section{References}

AA1000. AccountAbility principles standard [online], [cited 20 December 2015]. AccountAbility UK, 2008. Available from Internet: http://www.accountability.org/images/content/0/7/ 074/AA1000APS\%202008.pdf

Ambros, B.; Schlegelmilch, B. B. 2009. The new role of regional management. Basingstoke: Palgrave, Macmillan. 288 p. http://dx.doi.org/10.1057/9780230273870

Bachtler, J.; Gorzelak, G. 2009. Reforming EU cohesion policy: a reappraisal of the performance of the structural funds, in D. Bailey, L. De Propis (Eds.). Industrial and regional policies in an enlarging EU. Routledge.

Begg, I. 2010. Cohesion or confusion: a policy searching for objectives, Journal of European Integration 32(1): 77-96. http://dx.doi.org/10.1080/07036330903375115

Berger-Schmitt, R. 2000. Social cohesion as an aspect of the quality of societies: concept and measurement. EuReporting Working Paper 14. Centre for Survey Research and Methodology, Mannheim, 131.

Bernard, P. 1999. Social cohesion: a critique. Discussion Paper No. F-09. Canadian Policy Research Networks Inc., Ottawa. 5 p.

Boucher, G.; Samad, Y. 2013. Introduction: social cohesion and social change in Europe, Patterns of Prejudice 47(3): 197-214.

http://dx.doi.org/10.1080/0031322X.2013.814870

Brady, D. 2010, Rich democracies, poor peaple: how politics explain poverty. Oxford: Oxford University Press. 288 p.

Brakman, S.; Garretsen, H.; Marrewijk, C.; Witteloostuijn, A. 2006. Nations and firms in the global economy. An introduction to international economic and business. Cambridge: Cambridge University Press. 446 p. http://dx.doi.org/10.1017/CBO9780511811791

Brookes, S.; Grint, K. 2010. The new public leadership challenge. Basingstoke: Palgrave, Macmillan. 350 p. http://dx.doi.org/10.1057/9780230277953

Button, M. 2008. Doing security: critical reflections and an agenda for change. Basingstoke: Palgrave, Macmillan. 272 p. http://dx.doi.org/10.1057/9780230583634

Chan, J.; To, H.-P.; Chan, E. 2006. Reconsidering social cohesion: developing a definition and analytical framework for empirical research, Social Indicators Research 75(2): 273-302. http://dx.doi.org/10.1007/s1 1205-005-2118-1

Chang, S.; Gong, Y.; Way, S. A.; Jia, L. 2013. Flexibility-oriented HRM systems, absorptive capacity, and market responsiveness and firm innovativeness, Journal of Management 39: 1924-1951. http://dx.doi.org/10.1177/0149206312466145 
Cini, M.; Borragan, N. 2013. European Union politics. $4^{\text {th }}$ ed. Oxford University Press.

Council of Europe. 2005. Security and social cohesion. Deconstructing fear (of others) by going beyond stereotypes [online], [cited 12 January 2016]. Trends in social cohesion, No. 11. Council of Europe publishing. Available from Internet: http://www.coe.int/t/dg3/socialpolicies/socialcohes iondev/source/Trends/Trends-11_en.pdf

Crane, A.; Matten, D. 2010. Business ethics. Oxford: Oxford University Press. 624 p.

Dimeglio, I.; Janmaat, J. G.; Mehaut, P. 2013. Social cohesion and the labour market: societal regimes of civic attitudes and labour market regimes, $\mathrm{So}$ cial Indicators Research 111(3): 753-773. http://dx.doi.org/10.1007/s1 1205-012-0032-x

Forrest, R.; Kearns, A. 2001. Social cohesion, social capital and the neighbourhood, Urban Studies 38(12): 2125-2143. http://dx.doi.org/10.1080/00420980120087081

Ginevičius, R. 2009. Socioekonominių sistemų būklès kiekybinio ịvertinimo problematika, Verslas: teorija ir praktika 10(2): 69-83.

Ginevičius, R.; Hogeforster, J.; Hogeforster, M.; Jarke, P.; Odenrick, P.; Olczyk, M.; Starnawska, M. 2014. Innovative SMEs by gender and age around the mare Balticum. Hamburg: Baltic Sea Academy. 379 p.

Harrison, A. 2010. The business environment in a global context. Oxford: Oxford University Press. 400 p.

Heidenreich, M.; Petzold, N.; Natili, M.; Panican, A. 2014. Active inclusion as an organisational challenge: integrated anti-poverty policies in three European countries, Journal of International and Comparative Social Policy 30(2): 180-198. http://dx.doi.org/10.1080/21699763.2014.934901

Hix, S. 2007. Euroscepticism as anti-centralization: a rational choice institutionalist perspective, European Union Politics 8(1): 131-150. http://dx.doi.org/10.1177/1465116507073291

Hoyle, D. 2001. ISO 9000 Quality Systems Handbook [online], [cited 5 April 2016]. 4 ed. Completely revised in response to ISO 9000:2000. ButterworthHeinemann. Available from Internet:

http://pqm-online.com/assets/files/lib/books/holye2.pdf

Informations security and ISO 27001. Introduction. 2013 [online], [cited 5 April 2016]. IT Governance green paper. IT Governance. Available from Internet: http://www.itgovernance.co.uk/files/Infosec 101v1.1.pdf

ISO 14001. Environmental management systems - requirements with guidance for use (ISO 14001: 2004/Cor.1:2009). LST EN ISO 14001/AC.

ISO 26000 and the International Integrated Reporting $<I R>$ Framework briefing summary. 2015 [online], [cited 5 April 2016]. International Organization for
Standardization, Switzerland. Available from Internet:

http://www.iso.org/iso/iso_26000 and ir internati onal_integrated_reporting_en_-_lr.pdf

ISO 9001. Quality management systems. Requirements. $4^{\text {th }}$ ed. Reference number ISO 9001:2008(E). International Organization for Standardization, Switzerland, 2008.

Lobanova, L. 2015. Human resources management within the context of cohesion processes in the European Union: Doctoral dissertation [online], [cited 20 December 2015]. Vilnius: Technika. Available from Internet:

http://dspace.vgtu.lt/bitstream/1/1893/1/2337M\%2 0_Liudmila_Lobanova_Disertacija.pdf

Lobanova, L.; Melnikas, B. 2012. Cohesion in the European Union: new challenges for human resource management, in The $7^{\text {th }}$ International Scientific Conference „Business and Management 2012“, 10-11 May 2012 [online], [cited 20 December 2015]. Vilnius, Lithuania, 398-407. Available from Internet: http://leidykla.vgtu.lt/conferences/ BM_2012/international_economy/398_407_Loban ova.pdf

McCracken, M. 2003. Social cohesion and macroeconomic performance. Toronto, ON: University of Toronto Press.

Misiūnas, A.; Balsytè, I. 2009. The essence of sustainable social development and possibilities for measuring it, Intellectual Economics 1(5): 61-71.

Melnikas, B. 2012. Cohesion processes in the European Union: tendencies and new challenges, European Integration Studies: Research and Topicalities (6): $150-159$.

Molle, W. 2007. European cohesion policy. Abingdon: Routledge.

Norton, A.; De Haan, A. 2013. Social cohesion: theoretical debates and practical applications with respect to jobs. Background paper for the world development report 2013.

OHSAS 18001:2007. Occupational health and safety assessment series. Occupational health and safety management systems - requirements. OHSAS Project Group, 2007.

Oxoby, R. 2009. Understanding social inclusion, social cohesion and social capital [online], [cited 20 December 2015]. International Journal of Social Economics 36(12): 1133-1152. http://dx.doi.org/10.1108/03068290910996963

Rakauskienė, O. G.; Ivashinenko, N. 2011. The economic and social cohesion of EU: methodology of investigation, Intelektine ekonomika 5(4): 575-589.

SA8000. Social Accountability 8000. International standard by Social Accountability International, 2014.

Wiener, A.; Diez, T. 2009. European integration theory. Oxford: Oxford University Press. 295 p. 